\title{
GËRMIA - FROM A REGIONAL PARK TO THE PROTECTED LANDSCAPE
}

\section{Behxhet Mustafa $^{1,2 *}$, Florim Isufi ${ }^{3}$, Ndriçim Mustafa ${ }^{3}$, Bledar Pulaj $^{2}$ \& Avni Hajdari ${ }^{1,2}$}

\author{
${ }^{1}$ Institute of Biological and Environmental Research, University of Prishtina "Hasan Prishtina", \\ Mother Teresa Street, 1000 Prishtinë, Kosovo \\ ${ }^{2}$ Department of Biology, University of Prishtina "Hasan Prishtina", \\ Mother Teresa Street, 1000 Prishtinë, Kosovo \\ ${ }^{3}$ Department of Geography, Faculty of Mathematics and Natural Sciences, University of Prishtina \\ "Hasan Prishtina", Mother Teresa Street, 1000 Prishtinë, Kosovo
}

Mustafa, B., Isufi, F., Mustafa, N., Pulaj, B. \& Hajdari, A.: Gërmia - from a regional park to the protected landscape. Nat. Croat., Vol. 25, No. 1, 173-184, 2016, Zagreb.

This study took place in the Gërmia massif (Republic of Kosovo) and presents an overview of the current status of this protected area. The Gërmia Regional Park is one of the 173 protected areas in Kosovo. It received this status in 1987 (GZK, no. 43/87) from the Prishtina municipal assembly and covers an area of 1064 hectares. Its natural values have changed dramatically during the last decades, especially in terms of biodiversity. With the aim of evaluating the current situation of the Park's biodiversity, its flora, fauna and plant communities were investigated. The biodiversity of Gërmia comprises 610 vascular plant species (excluding weed species), 83 fungi, 14 mosses, 51 lichens, as well as 5 amphibian, 7 reptile, 32 bird, 19 mammal and 110 butterfly species. As a consequence of human activities, many plant and animal species in Gërmia are endangered. Taking into consideration its natural value and the threat factors around the area, it was proposed to extend the protected area to another 1167 hectares, and to harmonize its protection status with the Law of Nature Protection (i.e. to change the category from Regional Park to Protected Landscape (category V according to the IUCN).

Key words: regional park, protected landscape, biodiversity, endemic plants, relict plants

Mustafa, B., Isufi, F., Mustafa, N., Pulaj, B. \& Hajdari, A.: Gërmia - od regionalnog parka do zaštićenog krajolika. Nat. Croat., Vol. 25, No. 1, 173-184, 2016, Zagreb.

Istraživanje se odvijalo u masivu Gërmia (Republika Kosovo) i predstavlja pregled trenutnog stanja ovog zaštićenog područja. Regionalni park Gërmia je jedno od 173 zaštićena područja na Kosovu. Taj status je Park dobio 1987. (GZK, no. 43/87) od Skupštine grada Prištine, a pokriva područje od 1064 ha. Tijekom posljednjih desetljeća prirodne vrijednosti Parka su se dramatično promijenile, posebno u smislu biodiverziteta. Istraživani su flora, fauna i biljne zajednice Parka s ciljem procjene trenutne situacije biodiverziteta Parka. Biološka raznolikost Parka obuhvaća 610 vrsta vaskularnih biljaka (ne uključujući korovne vrste), 83 vrste gljiva, 14 vrsta mahovina, 51 vrstu lišajeva, kao i 5 vrsta vodozemaca, 7 vrsta gmazova, 32 vrste ptica, 19 vrsta sisavaca te 110 vrsta danjih leptira. Kao posljedica ljudskih aktivnosti, ugroženo je mnogo biljnih i životinjskih vrsta u Parku. Uzimajući u obzir prirodne vrijednosti i čimbenike ugroze, predlaže se proširivanje zaštićenog područja na novih 1167 ha, i usklađivanje statusa zaštite sa Zakonom o zaštiti prirode (tj. promjena kategorije iz Regionalnog parka u Zaštićeni krajolik (kategorija V prema IUCN-u).

Ključne riječi: regionalni park, zaštićeni krajolik, bioraznolikost, endemične biljke, reliktne biljke

\footnotetext{
* Corresponding author, e-mail: behxhet.mustafa@uni-pr.edu
} 


\section{INTRODUCTION}

The Republic of Kosovo has a territory of $10908 \mathrm{~km}^{2}$, with a population of more than 1.8 million, making it one of most densely populated countries in Europe, with an average population density of 166.9 inhabitants per $\mathrm{km}^{2}$ (ESK, 2013). In terms of nature values, i.e. geodiversity (geomorphologic, climatic, hydrological, pedological conditions), Kosovo is unique and is also very rich in terms of biodiversity. This all represents important values in terms of science, culture, education and tourism in Kosovo. Biodiversity and the overall environment are of great importance for Kosovo, and thereforethe country's Constitution states that nature and biodiversity, the environment and the national heritage are everyone's responsibility, while nature protection is regulated by the Law of Nature Protection. The main bodies responsible for implementation of the obligations arising from the Constitution and the Law for Nature Protection are the Ministry for Environment and Spatial Planning as well as the Agency for Environment Protection, with its institutes: Institute for Nature Protection, Institute for Spatial Planning and Institute for Hydrometeorology. The Institute for Nature Protection in consultation with external experts is responsible for assessment of natural values and for proposing protected areas in Kosovo. In Kosovo the national network of protected areas includes 173 natural protected areas, while 30 others (mainly natural monuments) have been proposed for protection. Protected areas in Kosovo cover an area of 118,913,95 ha or 10.99\% of Kosovo's territory. These areas include: 19 Strict Nature Reserves, 2 National Parks, 147 Natural Monuments, 3 Protected Landscape and 2 Nature Parks, some of them are presented in Fig. 1. The largest area is covered by national parks Bjeshkët e Nemuna with 62,488 ha (Law no. 04/L - 086) and Sharri with 53,469 ha (Law no. 04/L-087). Compared to other countries in the Balkans, the percentage of Kosovo's territory declared to be natural protected areas is satisfactory; the country is ranked after Sloveni, which has $12.5 \%$ of its territory as protected area (Protected areas in Slovenia, 2015) and Albania 12.57 \% (IUCN, 2015b), The percentage is higher than in Montenegro 9.047\% (MontenEgro FACTS GovernMent GUIDE SERIES, 2010), Macedonia 9\% (Melovski et al., 2011), Croatia 8.19\% (State institute For NATURE PRotection, 2015), Serbia 5.91\% (IUCN, 2015a) and Bosnia and Herzegovina, 2.6\% (Đug \& DrešKović, 2012).

The Gërmia Regional Park, one of the 173 protected areas of nature in Kosovo, lies close to Prishtina and because of its geographic position and beautiful landscape it is called the 'green balcony of Prishtina'. It was declared a protected area in 1987 by the assembly of Prishtina municipality and covers an area of 1064 hectares; however, the Regional Park category is not recognised by the recent Law for Nature Protection in Kosovo (Law no. 03/L-233).

Its geodiversity and biodiversity richness have been reported by several authors: for geology (Milovanovic \& Ciric, 1968); pedology (PavičEvić et al., 1974); flora (KRASNiQI, 1972, 1987; Krivoshej, 1989; Amidžić, 1988; Mustafa, 1998; 1999; Mustafa et al., 2008; Rexhepi, 1994, 2000; Veselaj, 2000; Veselaj et al, 2006.) and fauna (Mustafa \& Hoxha, 2002; JАКšÍ́, 2003). It is considered one of the richest areas in terms of biodiversity in Kosovo after Sharri and Bjeshkët e Nemuna National Parks. In the recent decades the populations of many species declined dramatically and certain other species became extinct. This has mainly happened due to the destruction of natural habitats by humans, consciously or unconsciously, for example: by expansion of the city of Prishtina and surrounding villages, by expansion of road traffic, construction of many buildings, inef- 


\section{MAP OF PROTECTED AREAS IN KOSOVO}

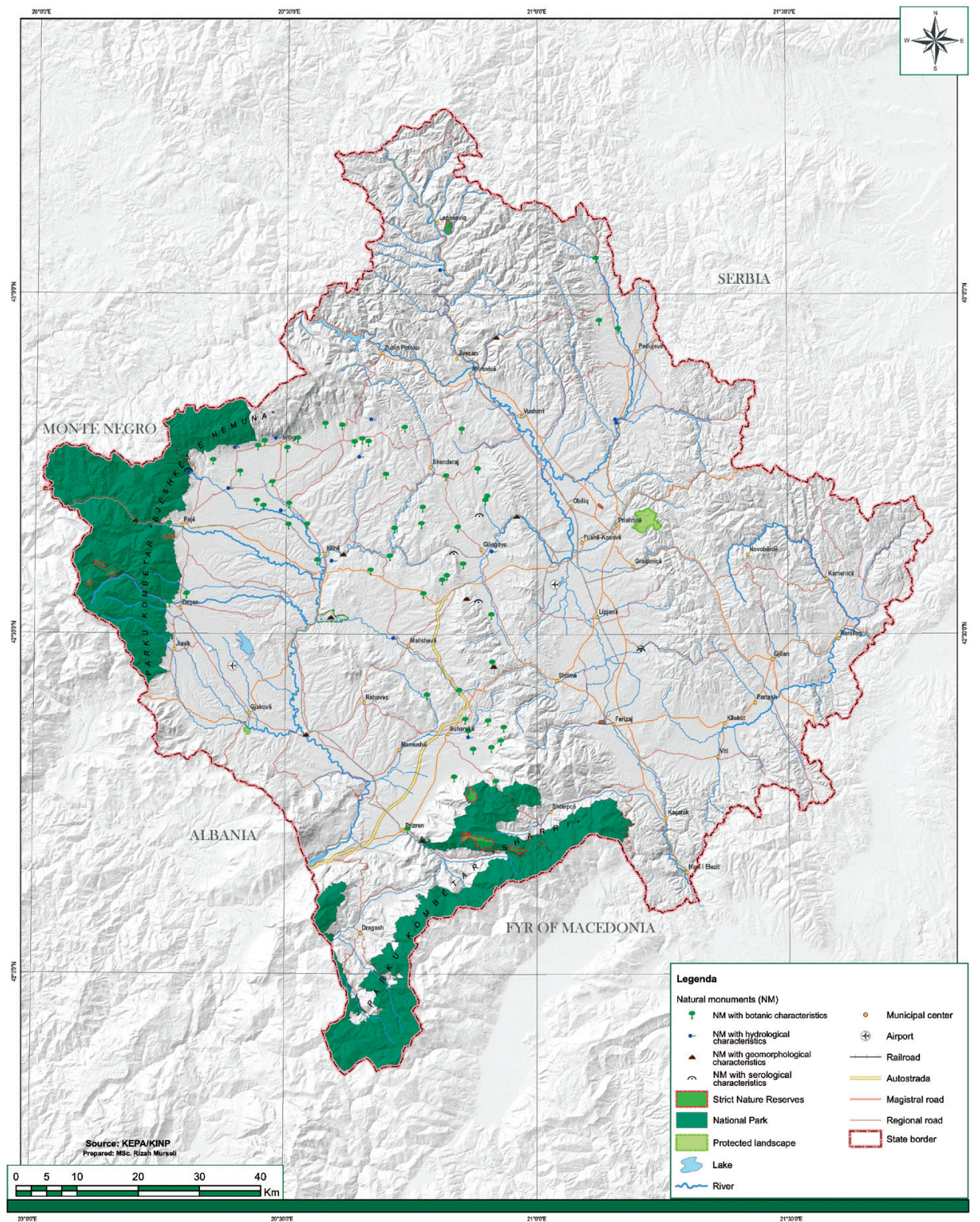

Fig. 1. Map showing protected areas in Kosovo (AMMK/IKMN, 2015)

fective management (uncontrolled logging of forests, illegal hunting, tree diseases and pests, waste disposal, air pollution and noise from vehicles entering from all sides of the park, etc. These are some of the reasons for undertaking this research to re-evaluate the natural values of Germia. 


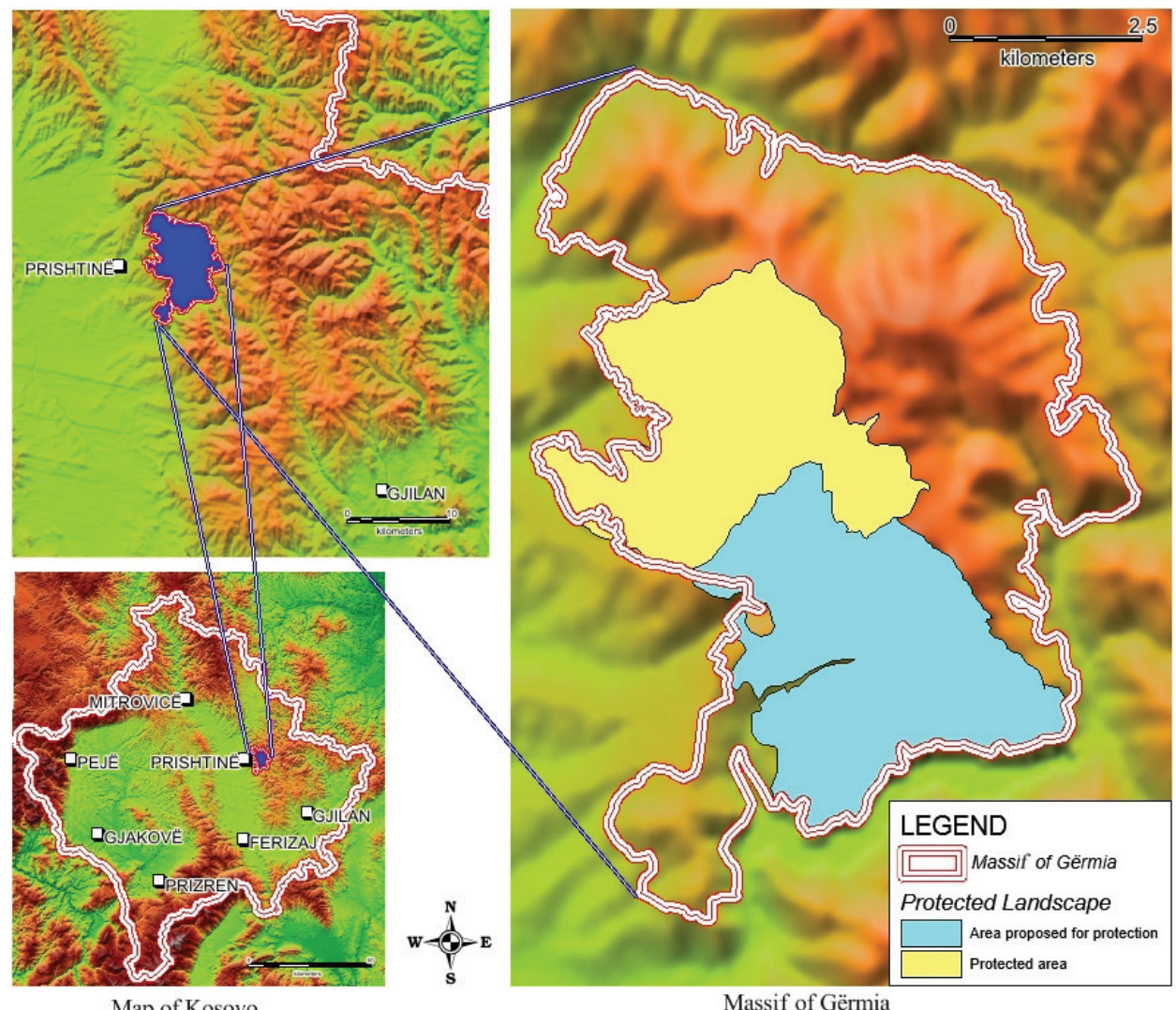

Fig. 2. Position of the Gërmia Massif, showing boundaries of the protected area and area proposed for protection.

The specific aim of this work is to evaluate the state of biodiversity with special emphasis on endemic, relict, endangered, extinct species, and plant communities as well as to re-evaluate its status as Natural Protected Area.

\section{MATERIAL AND METHODS}

For the assessment of biodiversity values, the available relevant literature was used. Field research for the evaluation of plant populations of interest was conducted during the period 2013-2014. Species were analyzed in terms of size and anthropogenic impact on their population, especially if vulnerable and prone to extinction by human influence. Taxonomic identification of plant species was undertaken using the relevant standard botanical literature (Demiri, 1981; PAparisto, et al., 1988-2000; Tutin et al., 1964; PAJAzitaj, 2004). Literature regarding animal species was reviewed, too, and the presence of mammals in Gërmia massif was evaluated by interviewing hunters and local inhabitants, using semistructured interviews. In order to evaluate human impact we compared the actual state of plant populations with previous results gathered from literature. 


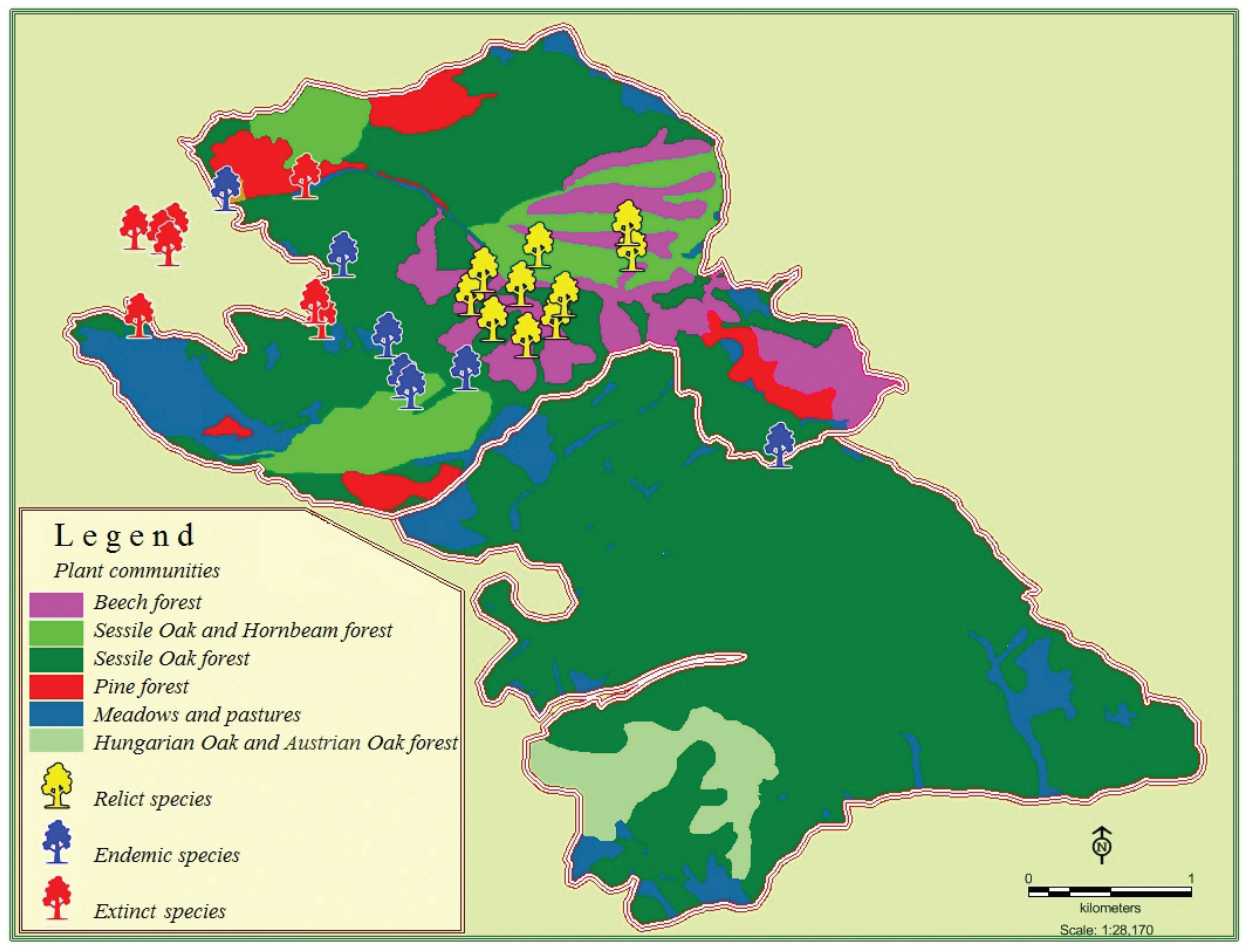

Fig. 3. Distribution of plant communities, relict, endemic and extinct species in Gërmia.

Results gathered during the field work were processed by GIS (Map Info software) and Remote Sensing (Global Mapper and Erdas Image) technologies (Fig. 3).

\section{Study area}

Gërmia Massif is a part of the Rhodope Mountains system, which stretches from the Karadak Mountains in the south to the Kopaonik Mountains in the north. It is located to the east of Prishtina, capital of Kosovo. It has a shape of an amphitheatre turned towards the city, which offers maximum adaptability for the purpose of recreation (Fig. 4). Along the main valley of Gërmia there is a road passing for about $3 \mathrm{~km}$, while around the Gërmia massif the entire system of roads is asphalted which enables access for monitoring and management of the area. In the south of the massif, the Badovci artificial lake and Prishtina Bear Sanctuary are situated. Within the protected area there are highest elevation points which offer the possibility to view the city of Prishtina and the central and northern part of Kosovo valley. The highest elevation is Butosit Hill with an altitude of $1095 \mathrm{~m}$ a.s.l. On Butosit Hill the sources of Vellusha and Badoc streams are located.

Because of its physical and geographic position, geological and pedological features, climatic conditions etc., Mt Gërmia is rich in terms of flora and fauna. Regarding its phyto-geographical aspects, Gërmia is a part of the Moesiac province which is a part of the Euro-Siberian-North American vegetative region. 


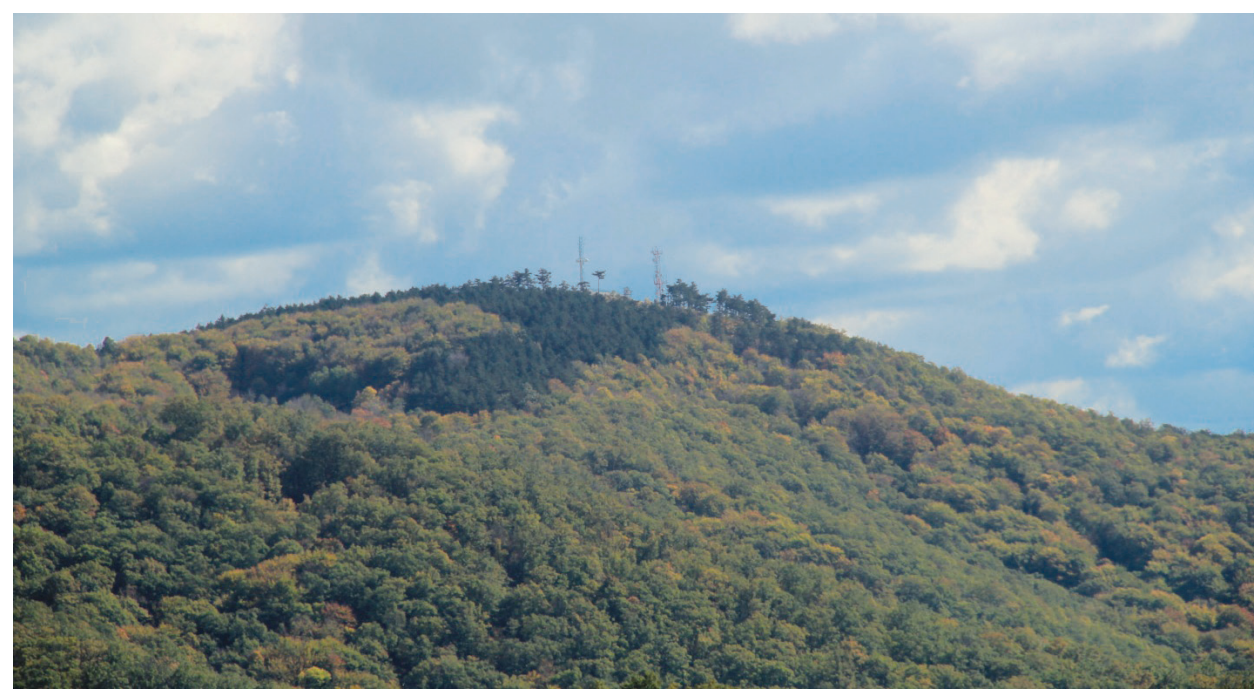

Fig. 4. Landscape of Gërmia (oak and pine communities) on Butosi hill

\section{RESULT AND DISCUSSION}

\section{Biodiversity and impact of human activities}

Gërmia is considered to be one of the richest areas in terms of biodiversity in Kosovo after the Sharri and Bjeshkët e Nemuna Mountains. Important ecosystems include beech and oak forest, shrubs, meadows, and a number of endangered flora and fauna species of national and international importance. In previous research into biodiversity (KrivošEj, 1989; Mustafa, 1999; Veselaj, 2000; Hajdari et al., 2009) in Gërmia 610 vascular plant species ( 82 families) were recorded (excluding weed species), 83 fungi, 14 mosses and 51 lichens. The flora of Gërmia also contains six Balkan endemic plant species. Many of the plant species are endangered, some of them within the protected area.

Tab. 1. Percentage (\%) of plant communities in protected area and in area proposed for protection

\begin{tabular}{|l|c|c|c|c|c|}
\hline Plant communities & $\begin{array}{c}\text { Protected } \\
\text { area } \\
\text { (hectares) }\end{array}$ & $\%$ & $\begin{array}{c}\text { Area proposed } \\
\text { for protection } \\
\text { (hectares) }\end{array}$ & $\%$ & $\begin{array}{c}\text { Total } \\
\text { (hectares) }\end{array}$ \\
\hline Meadows and pastures & 118,9 & 11,2 & 110,1 & 48,1 & 229,0 \\
\hline Sessile oak and hornbeam forests & 179,1 & 16,8 & 0,0 & 0,0 & 179,1 \\
\hline Beech forests & 172,1 & 16,2 & 0,0 & 0,0 & 172,1 \\
\hline Pine forests & 84,0 & 7,9 & 0,0 & 0,0 & 84,0 \\
\hline Hungarian and Austrian oak forests & 2,6 & 0,2 & 89,9 & 39,2 & 92,4 \\
\hline Sessile oak forests & 507,3 & 47,7 & 976,0 & 426,2 & 1483,3 \\
\hline
\end{tabular}


Tab. 2. Endangered and relict plant species in Gërmia

\begin{tabular}{|c|c|c|}
\hline $\begin{array}{l}\text { Plant species ( } 23 \text { species) } \\
\text { considered endangered in Gërmia } \\
\text { (not listed in the European Red } \\
\text { List): }\end{array}$ & $\begin{array}{l}\text { Endangered species (Balkan } \\
\text { endemics) within the protected area } \\
\text { and listed in the European Red List, } \\
\text { too (Bisz et al., 2011). }\end{array}$ & $\begin{array}{l}\text { Relict plant species in } \\
\text { Gërmia }\end{array}$ \\
\hline Cirsium candelabrum Griseb. & Dianthus cruentus Griseb. & Allium cupanii Raf. \\
\hline Coeloglossum viride (L) Hartm. & Dianthus gracilis Sibth. et Sm. & $\begin{array}{l}\text { Comandra elegant } \\
\text { (Rochel) Reichenb }\end{array}$ \\
\hline Corylus colurna $\mathrm{L}$. & Eryngium palmatum Panc. Et Vis. & Corylus colurna $\mathrm{L}$. \\
\hline Dianthus pinifolius Sibth.et Sm. & Lamium bifidum Cyr. & Daphne laureola $\mathrm{L}$. \\
\hline Euphorbia exigua L. & $\begin{array}{l}\text { Melampyrum heracleoticum Boiss. \& } \\
\text { Orph. }\end{array}$ & Hedera helix $\mathrm{L}$. \\
\hline $\begin{array}{l}\text { Haplophyllum suaveolus (De Cand.) } \\
\text { G. Don. }\end{array}$ & Stachys scardica (Griseb.) Hayek. & Staphyllea pinnata L. \\
\hline \multicolumn{3}{|l|}{ Lathyrus grandiflorus Sibth. et Sim. } \\
\hline \multicolumn{3}{|l|}{ Lathyrus sylvestris L. } \\
\hline \multicolumn{3}{|l|}{ Linum gallicum $\mathrm{L}$. } \\
\hline \multicolumn{3}{|l|}{ Listera ovata (L) R. Br. } \\
\hline \multicolumn{3}{|l|}{ Ophrys apifera Huds. } \\
\hline \multicolumn{3}{|l|}{ Orchis pallens $\mathrm{L}$. } \\
\hline \multicolumn{3}{|l|}{ Orchis purpurea Huds. } \\
\hline \multicolumn{3}{|l|}{ Orchis simia Lam. } \\
\hline \multicolumn{3}{|l|}{ Paeonia corallina Redz. } \\
\hline \multicolumn{3}{|l|}{ Paeonia decora G. Anderson. } \\
\hline \multicolumn{3}{|l|}{ Pedicularis comosa $\mathrm{L}$. } \\
\hline \multicolumn{3}{|l|}{ Ptilostemon strictus (Ten.) Greuter } \\
\hline \multicolumn{3}{|l|}{ Quercus trojana Weeb. } \\
\hline \multicolumn{3}{|l|}{ Ranunculus illyricus L. } \\
\hline \multicolumn{3}{|l|}{ Stachys officinalis (L) Trev. } \\
\hline \multicolumn{3}{|l|}{ Staphyllea pinnata $\mathrm{L}$. } \\
\hline Valeriana officinalis L. & & \\
\hline
\end{tabular}

As well as in Gërmia, rare and endangered species Ptilostemen strictus and Lathyrus grandiflorus in Kosovo are present in the vicinity of Decani (with small populations), Euphorbia exigua L. around the village of Hade in Obilic, while Pedicularis comosa L. in Kosovo is present only in Gërmia. Species that are endangered and have only a few individuals in Gërmia are Lathyrus sylvestris L. and Coeloglossum viride (L), Hartm., while Lathyrus grandiflorus was present at two localities in Gërmia, the first with only a few individuals, while the second population is now extinct. Among 52 medicinal plants present in Gërmia only Valeriana officinalis L. is an endangered species, with few individuals (about 50). 
Results obtained during the field research show the extinction of seven plant species. This means that in the Gërmia massif there are actually in total 603 vascular plants species, not 610 as reported previously (KRIVOŠEJ, 1989). Extinct species are: Cerathocephala falcata (L) Pers., which was present only in Gërmia, the extinction of this species thus meaning its extinction in Kosovo, Polystichum lonchitis Roth., Teucrium montanum L., and Calystegia sepium (L) R. Br. (Mustafa, 1999), Limodorum abortivum (L) Sw., Dictamnus albus L., Lychnis coronaria (L) Desr. (Fig. 3).

Regarding the mycoflora, up to now in Gërmia only the diversity of macromycetes was studied, because of the lack of relevant information for the groups of fungi. Previous research carried out in the area (VeselaJ, 2000) shows that Gërmia is a habitat for 83 species of macromycetes, belonging to two major classes: Ascomycetes ( 5 species) and Basidiomycetes (78 species). Regarding their natural habitats 71 species are present in deciduous forests (oak and beech forests), 4 species in pine forests, while 8 species were found on pastures and meadows. According to the substrate, 25 are epiphytic species (phytophilic), while 58 species live in soil substrate (geophytic). The most interesting macromycetes species are Boletus edulis, Cantharellus cibarius, Amanita cesarea which are listed in the Red Book of Albania (Misja, 2006). Hygrocybe coccinea, Russula virescens, Sarcoscypha coccinea are threatened species, too. Out of 83 recorded species of macromycetes, 8 are poisonous (Amanita phalloides, Amanita muscaria, Amanita pantherina, etc).

The diversity of ecosystems present in Gërmia provides living conditions for a variety of animal species, many of them rare and endangered, belonging to the Central European fauna. Like other groups in Kosovo, the fauna of Germia has not been studied sufficiently. However, during the previous research carried out in the area, 5 amphibian, 7 reptile, 32 bird and 19 mammal species were recorded (Mustafa \& Hoxha, 2002). JAKšIć (2003) recorded 110 species of butterflies, 19 species of which are endangered and listed in the IUCN Red List: Papilio machaon (Linnaeus, 1758), Pseudophiltes bavius (Eversmann, 1832), Plebejides pylaon (Fischer v. Waldheim, 1832), Argynnis pansora (Denis and Schiffermuller, 1775), Nymphalis antilopa (Linnaeus, 1758), Apatura iris (Linnaeus, 1758), Zerynthia polyxena (Denis and Schiffermuller, 1775), Pieris brassicae (Linnaeus, 1758), Lycaena dispar (Haworth, 1802), Thecla betulae (Linnaeus, 1758), Satyrium acaciae (Fabricius 1788), Cupido minimus (Fuessly, 1775), Maculinea arion (Linnaeus, 1758), Maculinea alcon (Denis and Schiffermuller, 1775), Plebeius argyrognomon (Bergstrasser, 1779), Melitaea aurelia (Nickerl, 1850), Apatura ilia (Denis and Schiffermuller, 1775), Hipparchia volgensis (Mayochin-Porshnjakov, 1952), Parnassius mnemosyne (Linnaeus, 1758). Butterfly diversity in Gërmia is richer than on Mt Pashtrik (101 butterfly species), which is one of the most investigated regions in Kosovo regarding butterfly diversity (JAKšić, 2007).

Birds of prey such as Aquila chrysaetos and Aquila heliaca are extinct or very rare. Interviews with hunters and local inhabitants indicate the probable extinction of 6 mammal species (Martes martes, Meles meles, Capreolus capreolus, Felis silvestris, Martes foina, Sus scrofa).

In the Gërmia area old individual trees can be found; in oak woodland at an altitude of $808 \mathrm{~m}$ an individual of Quercus pubescens Willd. with an approximate age of 200 years is present, while in beech forest at an altitude of $840 \mathrm{~m}$ there is an individual of Acer pseudoplatanus L. also approximately 200 years old. These individuals are potentially to be considered as Natural Monuments by the Institute of Nature Conservation.

The main area of Gërmia is covered by forests, about $95 \%$ of them indigenous until the 1960s, dominated by Quercus and Fagus communities (KRAsniqI, 1972). Because of 
anthropogenic impact the structure of forest in Gërmia is continuously changing. There are four types of forest associations now present: Quercetum frainetto-cerris scardicum Kras.; Querco-Carpinetum moesiacum; Quercetum moesiacum montanum Cer. et Jov. and Fagetumm moesiacum montanum (Krasniqi, 1972). According to KrivošEJ (1989) in the Gërmia massif Hungarian oak and Austrian oak forest dominates (Quercetum frainettocerris scardicum Kras.), while smaller areas are „occupied” by beech forest (Fagetum moesiacum montanum). Our field research shows that the protected area (1064 ha) and the proposed part for protection (1,176 hectares) is dominated by Sessile Oak forest (Quercetum moesiacum montanum Cer. et Jov.) (Tabs. 1 and 2; and Fig. 2). Beech forests are better preserved than oak forests, because of their position within the protected area.

Except for juniper (Juniperus communis L.), which is natural in Gërmia, other coniferous species are cultivated. A long time ago, 86.3 hectares of Gërmia were afforested with black pine (Pinus nigra Arn.) and white pine (Pinus sylvestris L.). In 1936 on Butosit Hill about 10 hectares were planted with black pine (Pinus nigra Arn.). In 1961 about 20 hectares of black pine (Pinus nigra Arn.) were planted, and about 1 hectare was planted with acacia (Robinia pseudoacacia L.) in the area near the swimming pool. In that period along the paved road in the recreational area black pine was cultivated in stripes (Pinus nigra Arn. and Pinus sylvestris L.). In 1962 the conifers were cultivated along the brook near the villages Kolovicë and Matiçan (Fig. 3). Our research confirmed that, except for the black pine community on Butosit Hill, which was partially destroyed during the NATO bombing in 1999, other parts of coniferous cultures are in relatively good condition.

Anthropogenic factors continuously influence natural plant communities, destroying indigenous plant communities, endangered plant species, and introducing new species, too. Fallopia japonica (Houtt.) Ronse Decrand and Robinia pseudoacacia L. have been registered as invasive plant species in Gërmia. Furthermore, as the result of the anthropogenic impact (logging, burning, etc.) about 20.5\% of the forests has been converted into meadows and pastures, mostly dominated by mesophytic and xerophytic meadows. Gërmia herbaceous vegetation consists of four associations (KRIVOšEJ, 1989), and these are: Inulo-Danthonietum alpinae; Astragalo-Calaminthetum alpinae; Hordeo-Xeranthemetum annui; Trifolio-Festucetum vallesiacae.

Our field research confirms that some parts of the forest have been converted into meadows and pastures as a consequence of anthropogenic activities. This conversion happened during the last two decades, but recently this process has been more intensive.

Throughout the ages and especially during and after the last war (1998/99), human activities have had a decisive impact on the area. Expansion of the city of Prishtina and surrounding villages, expansion of road traffic, construction of many buildings, ineffective management (uncontrolled logging of forests, illegal hunting (poaching), tree diseases and pests, waste disposal, air pollution and noise from vehicles entering from all sides of the park) have played a major role by directly damaging large parts of the plant communities and causing the extinction of plant and animal species. In recent years, the area of Gërmia has been visited by a large number of visitors, which impacts the surrounding environment especially by producing garbage. Measures have already been undertaken to keep under control the number of vehicles allowed to enter the area, but the park still has to cope with a high number of visitors and consequently with environment degradation and pollution. Forest exploitation is an illegal activity identified in area and has led to certain changes in the landscape, too. The introduction of a closed system for 
water collection (1988) in the area has serious implications on the Gërmia ecosystems and their biodiversity due to the significantly decreased availability of fresh water.

As a consequence of the anthropogenic activity, some plant and animal species became extinct, some of them are critically endangered, while some others are becoming rare and endangered. More or less the same situation has been confirmed in forest communities - they are partly completely degraded while other areas are in the process of degradation, resulting in landscape changes.

\section{CONCLUSIONS}

Germia was declared a protected area in 1987. It is actually managed by the public company Hortikultura, which is responsible for conserving the flora and fauna, waste management, phytosanitary cleaning, controlling entrance into the protected area. However, due to inappropriate management, the biodiversity of area has b een degraded, many species are endangered and some are extinct. The protection status of Gërmia should be re-established in order to enhance protection of the landscape and species found in area. To achieve that, the current status of protected area (Regional Park) has to be changed to Protected Landscape, which belongs to category V of protected areas according to the IUCN. Protected landscapes (Category V) by IUCN (1994) are defined as "areas of land, with coast or sea as appropriate, where the interaction of people and nature over time has produced an area of distinct character with significant aesthetic, ecological and/or cultural value, and often with high biological diversity" which is fully in harmony with the Law for Nature Protection in Kosovo. Its area should extend to other parts (around 1,176 ha are proposed) which are characterized by high biodiversity and landscape values.

Furthermore, the area actually needs an integrated and systematic approach and management of the natural heritage. The management should take into consideration the landscape and biodiversity conservation and recreation, with the actual possibility of sustainable use and ecotourism development. Furthermore in the future a systematic inventory of all flora and fauna species should be made. The park has to develop its own spatial and management plan covering all aspects of land, forest and vegetation, biodiversity, water, energy, waste, building and infrastructure. Such a management plan should also take into account the principles of sustainability, with not only environmental but also social and economic dimensions. It should be made with the agreement and participation of all stakeholders, addressing problems like waste management, construction, illegal logging, transport etc. Regarding the Kosovo Law for Nature Protection, the municipality is responsible for implementation of the management plan in protected landscapes (Category V by IUCN) and it is supervised by the Agency for Environment protection.

Received March 2, 2016

\section{REFERENCES}

AMMK/IKMN., 2015: Raport për gjendjen e natyrës në Republikën e Kosovës 2010-2014. Ministry of Environment and Spatial Planning, Prishtinë.

Amidžıć, L., 1988: Fiziološko-ekološka studija nekih karakterističnih vrsta (Paeonia coralina Retz., Asphodeline liburnica (Scop) Rchb. i Evonymus verrucosus Str.) u Grmiji kod Prishtine. Magistarski Rad. Beograd. 
Bilz, M., Kell, S.P., Maxted, N. \& Lansdown, R.V., 2011: European Red List of Vascular Plants. Luxembourg: Publications Office of the European Union.

Demiri, M., 1981: Flora ekskursioniste e Shqipërisë. Shtëpi Botuese e Librit Shkollor.

Đug, S. \& DrešKović, N., 2012: Nature Protection in Bosnia and Herzegovina: State and Perspectives. Journal for Geography, 7-1, 2012, 69-80.

ESK (Enti i Statistikës, Kosovë), 2013: https://ask.rks-gov.net

GZK (Official Gazette of Kosova), 1987: Vendim për vënie nën mbrojtje të kompleksit “Gërmia“ No 43/87, KK Prishtinë.

Hajdari, A., Mustafa, B. \& Hoxha, E., 2009: Mosses and lichens as indicator of air quality around power plants Kosova. Biotechniques for Air Pollution Control Proceedings of the 3rd International Congress on Biotechniques for Air Pollution Control. Delft, The Netherlands, pp. 265-268.

IUCN, 2012: IUCN Red List Categories and Criteria: Version 3.1. Second edition. Gland, Switzerland and Cambridge, UK: IUCN. iv + 32pp.

IUCN, 2015a: http://iucn.org/about/union/secretariat/offices/europe/resources/country_focus/serbia/ (January, 2015).

IUCN, 2015b: http://www.iucn.org/news_homepage/all_news_by_theme/protected_areas_news/?9082/ Advance-Albania (January, 2015).

JAKšıć, P., 2003: Crvena knjiga dnevnih leptira Srbije (Lepidoptera: Hesperioidea and Papilionoidea). [Red Data Book of Serbian Butterflies]. Zavod za zaštitu prirode Srbije, pp. 1-198, Beograd.

JAKšı́, P., 2007: Contribution to knowledge of the butterflies of mt. Pashtrik, Serbia. Acta Entomologica serbica, 12(2), 55-61.

KRASNiQI, F., 1972: Šumska vegetacija brdskog regiona Kosova. Zajedn. nauč. ustan. Kosova. Studije 27, 1-133, Prishtinë.

Krasniqi, F., 1987: Endemi u flori Kosova i problemi njihove zaštite. ANU. BiH. Posebna knjiga 83, 119-124, Sarajevo.

KrivošEJ, Z., 1989. Flora planine Grmije kod Prištine. Magistarska teza. Prirodno-matematički fakultet Univerziteta u Beogradu, Beograd.

LAW No. 04/L-086 on National Park "Bjeshkët e Nemuna”, 2012: Assembly of Republic of Kosovo.

LAW No. 04/L-087 on National Park "Sharri", 2012: Assembly of Republic of Kosovo.

LAW No.03/L-233 OF NATURE PROTECTION, 2010: Assembly of Republic of Kosovo.

Melovski, Lj., Hristovski, S., Brajanoska, R., Valevski, M., Sarov, A. \& Avukatov, V., 2011: Development of the representative protected areas system in the republic of Macedonia based on GIS Methodology. Zaštita prirode u XXI vijeku. Zbornik plenarnih referata (knjiga br. 1). Žabljak, Crna Gora, 95-109.

Milovanovic, B. \& Ciric, B., 1968: Geološka karta, Zavod za geološka i geofizička istraživanja Srbije. Beograd.

Misja, K. (ed.), 2006: Libri i Kuq i Faunës Shqiptare (Red Book of Albanian Fauna). Ministry of Environment, Forests and Water Administration, Tirana, pp 256.

MONTENEGRO FACTS GOVERNMENT GUIDE SERIES, 2010: Government of Montenegro Public Relations Bureau, Podgorica.

Mustafa, B. \& Hoxнa, E., 2002: Biodiversitei dhezonat e mbrojtura, Universiteti i Prishtinës, Prishtinë.

Mustafa, B., 1998: Basic characteristics of Flora and vegetation of Kosova an the danger of their disapperarance. AJNTS. Journal of Natural and Technical Sciences 5, 115-121. Academy of Sciences of Albania. Tiranë.

Mustafa, B., 1999: Flora dhe vegjetacioni i masivit malor të Gërmisë dhe masat që duhet të merren për mbrojtjen e saj nga shkatërrimi i mëtejmë. Akademia e Shkencave, Studime Gjeografike. No. 12. Tiranë.

Mustafa, B., Hajdari, A., Hoxha, E., Zhushi, F. \& Veselaj, Z., 2008: Potential areas of biodiversity for the Ecological Network Natura 2000 in Kosovo. Proceedings of International Conference on Biological and Environmental Science. Tiranë.

PajazitaJ, Q., 2004: Përcaktuesi i bimëve Pteridofite dhe Spermatofite, Universiteti i Prishtinës.

Paparisto, K., Vangjeli, J., Ruci, B., Mullaj, A. \& Qosja, X., 1988-2000: Flora e Shqipërisë. Vol. 1-4, Instituti i Kërkimeve Biologjike - ASHASH, Tirana.

Pavičević, N., Grujić, U., Milošević, Lj., Katalina, P. \& Vasić, G., 1974: Pedološka karta SAP Kosova, Beograd. 
PROTECTED AREAS IN SLOVENIA, 2015: http://www.parks.it/world/SI/Epage_menu.php?id=8 (January, 2015).

RexhepI, F., 1994: Vegetation of Kosova. Universiteti i Prishtinës.

Rexhepı, F., 2000: Bimët endemike të Kosovës.Universiteti i Prishtinës.

State Institute for Nature Protection of Croatia, 2015: http://www.dzzp.hr/eng/protected-areas/protectedareas-in-croatia/protected-areas-in-croatia-\%E2\%80\%93-national-categories-1137.html (January, 2015).

Tutin, T.G., V. H. Heywood, N.A. Burges, D.M. Moore, D.H. Valentine, S.M. Walters \& D.A. Webb (eds), 1964-1980: Flora Europaea, I-V. Cambrrige University Press. London.

Veselaj, Z., 2000: Të dhëna paraprake mbi mykoflorën e masivit të Gërmisë. Mikrotezë. Tiranë.

Veselaj, Z., Mustafa, B., Krasniqi, F. \& Hoxha, E., 2006: Species of international significance and their distribution in Kosovo. Bulgarian Academy of Science, Proceedings of IV Balcan Botanical Congress, 156-160. 